ART

\title{
ТЕНДЕНЦЙНН НАПРЯМКИ РОЗВИТКУ ХОРОВОЇ ЛІТУРГІЙНОЇ ПРАКТИКИ В ГАЛИЧИНІ КІНЦЯ ХІХ - ПЕРШОЇ ПОЛОВИНИ ХХ СТОЛІТЬ
}

\author{
Гуральна Світлана Степанівна \\ Украӥна, Кременецький педагогічний коледж Кременецької обласної гуманітарно-педагогічної \\ академії ім. Тараса Шевченка, викладач музичних дисииплін, \\ пошукувач кафедри музичної медієвістики та україністики Львівськоӥ національної музичної \\ академї ім. М. В. Лисенка
}

DOI: https://doi.org/ 10.31435/rsglobal_ws/30092018/6142

\section{ARTICLE INFO}

Received: 10 July 2018

Accepted: 16 September 2018

Published: 30 September 2018

\section{KEYWORDS}

Galicia,

choir,

composer,

samolivka,

jerusalimka,

liturgical creativity.

\begin{abstract}
The article highlights trends in the development of choral liturgical practice in Galicia at the end of the nineteenth and the first half of the 20th century, which were formed on the basis of governmental innovations in the system of education and cathedral and church changes in Western Ukrainian lands. In this, the active role of numerous spiritual and secular choral ensembles had played an important role. At the same time, certain influence were played by touring groups, which, with the spiritual programs of works of the Dnieper-Dnieper composers, considerably deepened the evaluation criteria as the work of the Galician authors as well as the performing level of creative groups. All this testified to the need of Ukrainians in the spiritual cultural and artistic life, about comprehension of the essence of the ritual and chorister repertoire and the development of the national style of choral music. Confirmation of these processes was the spiritual choral heritage of the Galician composers of the late nineteenth and the first half of the twentieth century, represented in a wide genre variety.

Thus, the article outlines the traditional and original author's approaches to the creation of liturgical music within the bounds of the statutory ritual system, the concept of «samolivka» and «jerusalimka» is illustrative for this period.
\end{abstract}

Citation: Гуральна Світлана Степанівна. (2018) Tendentsiini Napriamky Rozvytku Khorovoi Liturhiinoi Praktyky v Halychyni Kintsia XIX - Pershoi Polovyny XX Stolit. World Science. 9(37). doi: 10.31435/rsglobal_ws/30092018/6142

Copyright: (C) 2018 Гуральна Світлана Степанівна. This is an open-access article distributed under the terms of the Creative Commons Attribution License (CC BY). The use, distribution or reproduction in other forums is permitted, provided the original author(s) or licensor are credited and that the original publication in this journal is cited, in accordance with accepted academic practice. No use, distribution or reproduction is permitted which does not comply with these terms.

Введення. У численних дослідженнях, присвячених українській церковно-музичній творчості кінця XIX - першої половини XX ст., на сьогодні фактично відсутнє вивчення хорової літургійної практики та дослідження їі впливу на стилістику духовних творів композиторів у регіональному контексті. Галичина, для якої характерною є поліконфесійність суспільства із виокремленням в зазначений період провідної ролі Греко-Католицької Церкви, демонструє яскравий потенціал духовно-мистецької, а особливо хорової, творчості, що відіграла важливу роль у розвитку краю. Тому метою статті стало сформувати уяву про церковно-співочі традиції Галичини та виокремити тенденційні 
напрямки розвитку хорової літургійної практики, які вплинули на становлення стилістично відмінних концептів композиційного прочитання церковних текстів.

Результати дослідження. Урядові нововведення в системі освіти, усталення роботи різнорівневих навчальних закладів (школи, семінарії, академії), покращення видавничої діяльності та соборно-церковні зміни були зумовлені тісною співпрацею греко-католицького духовенства iз провідними галицькими культурно-мистецькими діячами (диригентами iз професійною музичною освітою, вихідцями із священицького середовища, аматорами хорового мистецтва). Тому, істотні зрушення у напрямку покращення музичної підготовки майбутніх регентів та церковних композиторів здійснювалися не тільки завдяки поширенню практикування вивченого, а й за наполегливої організації концертного життя в Галичині.

Активна виконавська діяльність численних хорів духовного та світського спрямування передбачала не тільки супровід богослужінь, але й співпрацю колективів на значимих культурно-мистецьких акціях, що сприяло обміну співацьким досвідом та представленню яскравих засобів музичної виразності. Це, з одного боку демонструвало запотребованість українців в культурно-мистецькому житті, що активізувало композиторську творчість 3 тенденцією до підвищення іiі професійного рівня. Натомість з іншого - через впровадження й осмислення літургійного репертуару поруч із засвоєнням обрядово-співочої естетики, формувалися локальні відмінності у трактуванні національного стилю церковної музики. Підтвердженням зазначених процесів стала духовна хорова спадщина галицьких композиторів кінця XIX - першої половини XX ст., представлена у широкому жанровому розмаїтті i, що цікаво, з доволі різною інтерпретацією текстів окремих частин богослужіння.

Важливо, що значний пласт церковно-музичних творів належить передусім композиторам-священикам i регентам церковних хорів, які виявляли прихильність до побутуючих регіональних церковно-співочих традицій. Орієнтуючись на часто вельми помірні виконавські можливості церковних хорів вони усталювали певні особливості стилістики: «Знання місцевих співочих традицій, ритуальних особливостей i парафіяльних потреб, притаманне кожному з них, створювало домінуючі установки творчості. Пишучи музику для конкретних колективів, вони мали враховувати їхні можливості. Регент, який був i композитором, і вчителем співу для вихованців, під час підготовки до виконання своїх творів міг досягти того бажаного звучання, яке засвоювалося й поширювалося як певний слуховий “архетип” чи взірець авторського музичного мислення з усіма його особливостями» $[8$, С. 110]. Водночас варто враховувати, що численні випадки профанування літургійного співу нефаховими регентами в аматорських хорах сприяли збереженню у богослужбовій практиці регіональних виконавських орієнтирів та панування напівпрофесійного хорового співу, який істотно залежав від інтеграції фольклорної з академічною манерою виконання [3, С. 8]. Тому й враження від таких богослужінь були неоднорідними, а у сфері музичної творчості вони стимулювали розвиток стилістично протилежних тенденцій.

Відтак, у творенні літургійної музики в межах уставно-обрядової системи увиразнилися два підходи: перший, що базувався на використанні і перекладенні традиційних одноголосих (монодійних) напівів, іноді 3 використанням в гармонізації елементів фольклорного багатоголосся та другий підхід, що презентував оригінальну авторську творчість західноєвропейського зразка на тлі тих чи інших мистецьких віянь, в певний спосіб визначену церковно-співочими традиціями i паралітургійними функціями, включно із зростаючим впливом василіянського піснярства, елементів народної пісні та поглиблення критеріїв виконавського і композиторського професіоналізму.

Зокрема, виникаючи у містечкових і сільських церквах ${ }^{1}$, літургійний і паралітургійний доробок першого напрямку ще на початку 1910-х років був зорієнтований на самолівковий спів. Це відображено у не тільки декларативних, а й концептуальних обгрунтуваннях у статтях Є. Турули («Потреба реформи богослужбового співу у греко-католицьких церквах», 1913) та С. Людкевича (передмова до «Літургії», стаття «Справа нашого церковного співу», 1922). Так, серед багатьох обговорюваних проблем С. Людкевич наголошував на вартості самолівки: «...наша самолівка, полишена без опіки, сама собі, не відживлювана ніяким кращим культурним впливом, уже зводиться нінащо. Але все ж таки ступінь іiі занепаду порівняно менший, чим «артистичного» хорального співу. Вона, хоч уже й завмерла і скостеніла, то все ж таки заховала

\footnotetext{
1 Як-от в Денисові (тепер Козівський район Тернопільської області), Гримайлові (тепер Гусятинський район Тернопільської області), Острові (Тернопільський район Тернопільської області), Стриганцях (Стрийський район Львівської області) [4, С.85-86].
} 
давній свій образ і характер; натомість хоральний спів здавна вже затратив до крихти релігійний, набожний характер, а затим - всякий вираз і естетику» [10, С. 245]. Тому відсутність необхідного забезпечення нотною продукцією церковних хорів, некритичний вибір ними репертуару (особливо респонсорію, що за характером виконання не відповідає «примітивним вимогам естетики і релігійного виразу») та стан церковного співу в Галичині зумовлювали появу низки творів, зорієнтованих на помірні виконавські можливості.

Істотного значення в утвердженні першого напрямку набуває осмислення специфіки всенародного (загальнонародного) співу, що функціонував у двох своїх різновидах: самолівка, яку також називали чи дяківкою та єрусалимка. Перший різновид богослужбового співу сформувався у сфері освітньої підготовки дяків і церковно-співочих кадрів. Дяківський інститут у той час, як і зараз, жодним чином не мислився як «виконавський». Від дяків вимагалося насамперед знання ритуалів та поширених у тій чи іншій місцевості розспівів. Традиції дяківського співу могли бути зорієнтовані винятково на взірці митрополичих храмів, або на локально-регіональні особливості народного інтонування. На цій основі дослідник церковного співу Ф. Стешко акцентує увагу на тому, що самолівка є одноголосим або гуртовим унісонним співом спокійного характеру [12], де при речитації одного звуку у верхньому голосі у всіх інших голосах він дублюється, що надає мелодиці статики й апелює до стійкості і ствердного характеру проголошуваного тексту.

За свідченнями Н. Костюк, «самолівка» не є винятково одноголосим співом, а швидше варіантом багатоголосого розспіву дяківських наспівів, завчених напам'ять зразків із рукописних ірмологіонів [9, С.18]. Ж. Зваричук зазначає, що самолівка являє собою індивідуальний виконавський стиль конкретного співака в конкретній ситуації [2]. Л. Кияновська стверджує, що «самуїлівка» - поширена у греко-католицьких храмах на початку XIX ст. манера співу, заснована на речитативному розспіві, 3 низхідним терцієвим або секундовим ходом наприкінці фрази (займає 1-2 такти) з частим закінченням у каденції тонічною терцією у найвищому голосі. Такий спосіб співу був простим для виконання i не вимагав фахової підготовки, тож широко використовувався, особливо в невеликих містечках і селах [6, С. 67, 92.].

Єрусалимка ж навпаки, була пристосована до багатоголосої виконавської практики від триголосся до семиголосся. Для неї важливим було співвідношення партій, загальне звучання та темпові параметри. П. Бажанський, як яскравий представник побутування єрусалимки у хоровій духовній творчості, серед питомих ii властивостей виокремлює чітке пофразове дихання, наближення до псалмодійного читання, специфічність ритмічної організації, що вимагає мобільності метро-ритмічного чуття у співаків, певну «рівноправність голосів» із можливістю виокремлення із загальної фактури звучання голосу провідного співака (тобто голосу, в якому розташована автентична мелодія) [1, С. 12]. Власне розуміння виконавських сил єрусалимкового багатоголосся Бажанський подає так: «Склад сего 7 голосового церковного хора виходить після нашої думки на слідуючий: 1. Прим, голос мужескій, тенор, ведучій мелодію. 2. Втур, голос мужескій, тенор, ідучий 3-ми до мелодії і часом сходиться з басом. 3. Дишкант, голос дитячий, unisono ідучий $з$ примом Sopr. 4. Дишкант, голос дитячий, Alt, ідучий unisono з тенором. 5. Тенор, голос мужескій, тримаючий домінанту верхом по над прим, однотонно тому донесений. 6. Альт, голос дитячий Alt, ідучий unisono $з$ тенором. 7. Бас, голос мужескій, ідучий часто 3 втуром, а деколи має смілі скоки скалі 1-4-5» [1, С. 74]. Він дає детальне аргументування деяких темпових параметрів з передбаченим широким асортиментом використання - від Largo до Allegro [1, C. 71]. Згідно спостережень Бажанського, єрусалимка любувалась в Sola-x, чистих або дуетових, у несподіваній появі повного хору.., в наслідуванні фраз (дуже старої забитки), а також у монотонно гудячому тенорі по верх мелодії переважно на примі домінантової гармонії [1, 72-73]. Нотографічно здавна вона записувалася в один голос із обов’язковими вказівками Solo, Sopr., Bass, duo, всі [1, 71]. Загалом, у музичній тканині єрусалимки переважає діатоніка, а підголоски та елементи гетерофонного викладу практично уникаються: інколи в унісон могли сходитися альт і бас або тенор і бас. Зрідка допускаються прохідні та допоміжні діатонічні та хроматичні звуки у середніх голосах, якщо вони доповнюють компломентарно рух мелодії у верхньому голосі. Показово при цьому, що сам П.Бажанський констатує як спорідненість понять «самолівка» та «єрусалимка» на основі використання тверджень «самолівка на єрусалимку» та «єрусалимка на самолівку», так і надає їм принципово відмінних ознак.

Та все ж певну роль у формуванні стилістики духовно-хорової музики галицьких композиторів відіграли й інші чинники, серед яких виокремлюється вплив гастролюючих високопрофесійних колективів (Українська республіканська капела О. Кошиця, Український Наддніпрянський хор Д. Котка). Репрезентовані ними літургійні та паралітургійні твори, написані 
переважно наддніпрянськими композиторами, захоплювали виским професіоналізмом, що відчутно впливало на критерії оцінювання власних творчих задумів і виконавського рівня навіть провідних колективів краю. Притаманний цим творам синтез давніх принципів розспіву 3 багатоголосим викладом (в тому числі й $з$ підголосково-поліфонічним багатоголоссям гуртового співу), а також інтонаційністю національної народнопісенної творчості були частково перейняті галицькими композиторами, зумовлюючи відчутне оновлення їх духовної творчості.

Важливо відзначити, що композиторська практика в ділянці духовної музики розвивалася переважно на основі канонічних жанрів християнського обряду. До таких найчастіше відносилася «Літургія» або «Служба Божа», а також вінчання і панахида.

Звертаючись до дефініції поняття «літургія», варто зазначити, що це визначення походить 3 стародавньої Греції і означає всяке діло людини, яке робиться на користь цілого народу (податок, десятина, приношення жертви [Євр. 8:6; 9:21])...), тобто громадську службу. В апостольські часи літургія мала назву «ламання хліба», або «агапа» (з грецької agapê - «вечеря любові»). Починаючи 3 IV ст. слово «літургія» стало технічним виразом для євхаристійного жертвоприношення, тобто для означення Служби Божої як усталеного за структурою циклу, в якій Богові віддається найвища честь i поклін через молитви, пісні, гимни та найголовніше через приношення Безкровної жертви Нового Завіту - хліба і крові Ісуса Христа. При цьому варто відзначити, що у широкому значенні літургія охоплює всі публічні вияви богопочитання св. Церкви, а у вузькому - обмежується лише євхаристійним жертвоприношенням (Службою Божою) [11].

До компонування найбільш вживаної в церковному році Літургії св. Івана Золотоустого, зверталося багато галицьких композиторів, зокрема П. Бажанський, О. Нижанківський, М. Копко, В. Матюк, С. Людкевич, Д. Січинський, Я. Ярославенко, Й. Кишакевич, Т. Купчинський та ін. Цікаво, що існуючі в суспільстві того часу активні дискусії щодо наповнення і тривалості самого обряду літургії, принципово не вплинули на структуру відповідних творів. До того ж, утвердження канонічної чинопослідовності провінціальним Синодом восени (1891) і «Типіком» І. Дольницького (1899), як і доступні для ознайомлення нотні видання 3 інших регіонів, спонукали до дотримання вже усталених нормативів авторських циклів. В них переважно охоплювались незмінні піснеспіви, хоча у деяких випадках було залучено й змінні, як-от тропарі, кондаки і прокимни. Щодо виконавського складу, то варіанти викладу також були стабільними: дво-, три- і чотириголосі твори для однорідних або мішаних хорів.

Стилістична відповідність літургійної творчості відзначалася достатньою поміркованістю. Композитори як старшого покоління, так і молоді митці у більшості випадків дотримувались усталених в регіоні традицій і на цьому ж грунті демонстрували різні творчі результати. Виявлення індивідуальних композиторських рис того часу відображало поєднання літургійної консервативності поряд із залученням народнопісенних засобів музичної виразності, а також західноєвропейських елементів музичного мовлення, яскраво висвітленого у домінуючих версіях розвитку регіонального церковно-співочого стилю. «В галицькій музиці, - пише О. Козаренко, кожен із композиторів мав свій стильовий орієнтир, який кидав додатковий естетичний “відсвіт" на загальну картину творчості митця, при чому це було не механічне відтворення певної манери чи стилю, а оригінальна творчість, “вільне ширяння” в обраному естетичному просторі, що часто-густо збагачувало саму стильову модель української музичної сецесії» [7, С.164]. На сферу богослужбової творчості чітко проектуються і спостереження Л. Кияновської щодо співіснування поряд 3 виразними романтичними тенденціями стремління до «обережного оновлення» музичної мови. Відтак, упродовж першої половини ХХ ст. «розмежування тенденцій романтичного мислення, 3 орієнтацією на різні художньо-естетичні еталони» означало «продовження регіональної традиції, черговий етап перетворення старогалицької пісенної та церковної традицій, здобутків “перемишльської школи”, але вже у більш складних образах, породжених fin de siècle ...» [5, С.140-141].

Задля виявлення динаміки творчого процесу важливим є не тільки хронологічнолінійний підхід до обраних для аналізу творів, але й спостереження за співвідношенням балансу між різними тенденціями у цій сфері. Тому інтерес викликають зразки, що належать до концепційно різних стилістичних напрямків - від вкрай консервативного, традиційного для церковно-співочого середовища із присутніми народнопісенними елементами, що відбивало помірковані запити парафіяльних хорів аж до виразно авторського стилю, із залученням здобутків західно-європейських знакових систем, що сукупно формувало річище стильового оновлення хорової літургійної практики в Галичині кінця XIX - першої половини XX ст. 
Висновки. Отож, суспільно-релігійна ситуація в Галичині зумовила відповідний рівень церковно-співочої освіти та створила сприятливі умови для розвитку літургійного хорового стилю. Це передбачало практикування самолівкового виконання у поєднанні із вагомим впливом світського та запровадженого в церквах хорового багатоголосся. На цій основі композитори творили більшість богослужбових циклів для виконання напівпрофесійними хорами і лише незначна кількість творів виявляла суто професійні вокально-хорові концепти авторського втілення.

\section{ЛITEPATУРA}

1. Бажанський П., священник. Исторія руского церковного пенія. Л.: Типографія Ставропігійського Института, $1890 .-8+86$ с.

2. Зваричук Ж. До питання про галицькі церковно-співочі традиції/ Ж. Зваричук // Студії мистецтвознавчі. К.: Видавництво ІМФЕ, 2007. Ч.2 (18). - С. 26-33.

3. Зваричук Жанна Йосипівна. Богослужбове хорове виконавство Галичини XIX століття [Текст] : автореф. дис... канд. мистецтвознавства: 17.00.03 / Зваричук Жанна Йосипівна; Ін-т мистецтвознав., фольклористики та етнології ім. М. Т. Рильського НАН України. К., 2009. - 19 с.

4. Зваричук Ж. Й. Богослужбове хорове виконавство Галичини XIX століття: дис... канд.мистецтвознавства: 17.00.03 / Зваричук Жанна Йосипівна. ІМФЕ ім. М. Т. Рильського. К., 2009. - 212 с.

5. Кияновська Л. Галицька музична культура XIX-XХст./ Любов Кияновська. // Навч. посібник. Чернівці: Книги XXI, 2007. - 424 с.

6. Кияновська Л. Стильова еволюція галицької музичної культури ХІХ-ХХст. / Любов Кияновська. Тернопіль: СМП «Астон», 2000. - 339 с.

7. Козаренко О. Феномен української національної музичної мови / Олександр Козаренко. Львів: Наукове Товариство ім. Шевченка, 2000. - 286 с.

8. Костюк Н. Богослужбова музична культура // Історія української музики: У шести томах. К., 2009. T. 2: XIX ст. - C. 70-145.

9. Костюк Н. Богослужбова творчість Вербицького: можливості оновлення критеріїв оцінки в культурностильовому контексті // Українська музика: наук. часопис / [засн. ЛНМА імені М. В. Лисенка; гол. ред.. І. Пилатюк], 2011. Львів, 2015. - С. 156-168.

10. Людкевич С. Справа нашого церковного співу / С. Людкевич // Український Вістник. 1921. 2 серп. Ч. 150. - С. 2-3; Ч. 151. - С. 2-3. // Людкевич С. Дослідження, статті, рецензії, виступи. Т.2./ Упорядкування, редакція, переклади, примітки і бібліографія 3. Штундер. Львів: Вид-во М. Коць, Дивосвіт, 2000. - С. 244-248.

11. Соловій М. Божественна Літургія. Історія-розвиток-пояснення. Львів: Свічадо, 1999. -440 с.

12. Стешко Ф. 3 історії української музики XVII ст. (Церковна музика в Галичині) // Українська музика. І ч. 1937. №8 - С. 101-105; II ч. 1938. №1. - С. 2-5; II (Продовження). 1938. №2. - С. 21-27. 